\title{
Perception and Adverse Effects of Patients after using Propolis- Containing Dentifrice
}

\author{
Mônica Do Amaral Silva ${ }^{1,2, *}$, Lídia Audrey Rocha Valadas' ${ }^{1}$, Francisco Josimar Girão Júnior', Guilherme Antônio Lopes De Oliveira², Ana \\ Cristina de Mello Fiallos ${ }^{1}$, Edilson Martins Rodrigues Neto' ${ }^{1}$, Emerson Dias Ponte' ${ }^{1}$ Pedro Alves de Souza Neto', Gandhi Radis Baptista ${ }^{1}$ \\ 'College of Pharmacy, Dentistry and Nursing, Federal University of Ceara, Fortaleza, CE, BRAZIL. \\ ${ }^{2}$ Chrisfapi University, R. Acelino Rezende, 132 - Fonte dos Matos, Piripiri - PI, BRAZIL.
}

\begin{abstract}
Objective: The objective of this study was to evaluate the perceptions of patients undergoing orthodontic treatment, for the perceptions and possible adverse effects after using toothpaste based on Brazilian Red Propolis (BRP). Materials and Methods: This is a longitudinal clinical study. 40 participants used a toothpaste BRP three times a day for a total of four weeks. After 4 weeks, the end of the study, participants completed a questionnaire with a scale ranging from 0 to 10 for parameters such as taste, nausea, cleanliness, ease, irritation, odor and sense of taste change. Results: The taste, cleaning ability, ease and odor had high scores. There were no reports as to the possible adverse events such as irritation and change in taste. One participant reported the occurrence of nausea after brushing, indicating score 1. Conclusion: The use for 4 weeks of the BRP toothpaste
\end{abstract}

did not cause adverse effects and had a good acceptance by the users. Key words: Biofilm, Natural Products, Perception, Propolis, Toothpaste.

Correspondence

Prof. Mônica Do Amaral Silva,

Federal University of Ceara, 1210 Capitao Francisco Pedro, Rodolfo Teófilo, CE, BRAZIL.

Phone: +558533668000

Email: monicaamaralufc@gmail.com

DOI: $10.5530 / j y p .2019 .11 .86$

\section{INTRODUCTION}

Many micro-organisms that colonize both the tooth surface and adjacent structures such as the gingival, buccal mucosa and tongue inhabit the oral cavity. The diversity and complexity of the oral microbiota in different areas is established by the environmental characteristics of the cavity, such as high humidity, relatively constant temperature (34 to $\left.36^{\circ} \mathrm{C}\right) \mathrm{pH}$ near neutrality and nutrient availability. Factors such as age, diet, hormones, salivary flow, hygiene, alcoholism and others determine variability of the composition of the oral microbiota. It is known that in patients who are undergoing orthodontic treatment it is common the appearance of caries and gingivitis because of the difficulty of cleaning and plaque accumulation. ${ }^{1,2}$

Studies report the use of antimicrobial products in controlling periodontal disease in formulations such as toothpastes and mouthwashes, which are indicated especially in controlling gingivitis in children and teenagers. ${ }^{3}$ Chlorhexidine is the most widely used antimicrobial in the treatment of gingivitis, being quite effective. However due side effects such as taste disturbance, tooth staining, recolonization, mucosal irritation, among other things, seeks to effectively substances but with minor adverse effects. ${ }^{4,5}$

The use of natural products as an alternative therapy dates back to ancient age and they are essential in the production of new drugs. Dentistry research on natural products have increased in recent years due to the search for new substances with greater pharmacological activity, lower toxicity and greater biocompatibility, in addition to having more affordable value to the population.,

Propolis is presented as a resin complex responsible for sealing of bee hives (Apis mellifera) and from the collection of them in various types of vegetables. Currently we have knowledge of at least 200 types of compounds identified in propolis from different geographical sample and botanical diversity. The main constituents are prenylated phenolic acid, lignans, terpenes, terpene alcohols and coumaric p-derivatives. ${ }^{7}$
The chemical composition of propolis depends on vegetation around the hive. Most of propolis are composed of $50 \%$ vegetable resin and balsam, $30 \%$ wax, $10 \%$ essential oils and aromatic compounds, $5 \%$ pollen, $5 \%$ other substances. ${ }^{8}$ The Brazilian propolis was classified into 13 different types according to their physicochemical characteristics and geographic location. The latest, red propolis has been classified as type 13 based on its unique chemical composition that is known for its high content of isoflavonoid, with particular interest in neovestitol and vestitol for antioxidant activity. ${ }^{9}$

The Neovestitol and Vestitol are the main bioactive compounds of Brazilian Red Propolis and exhibit anti-inflammatory and antimicrobial activity, with potential of action at a dose and concentration. Neovestitol and vestitol are isoflavones and can modulate the inflammatory processes such as those involving periodontal diseases and soft tissue changes. Studies also show the therapeutic effect of the propolis extract on inhibition of cariogenic microbial agents, being presented as a clinical option of low toxicity. ${ }^{9}$

Several studies show the therapeutic effect of propolis extract on inhibition of cariogenic microbial agents, moreover it appears as a clinical option low toxicity and high biocompatibility. ${ }^{10,11}$

The aim of this study was to evaluate the perceptions of patients undergoing orthodontic treatment, for the sensations and possible adverse effects after using BRP toothpaste.

\section{MATERIALS AND METHODS}

\section{Extract of Brazilian Red Propolis and preparation of toothpastes}

The propolis extract was collected in the city of Marechal Deodoro (Lattitude 44555 South $9^{\text {th }}$, latitude $35^{\circ} 52080$ West and elevation of 18.1 $\mathrm{m}$ above sea level), region with geographical indications granted by the 
National Institute of Industrial Property (INPI) in the state of Alagoas, Brazil. It used $150 \mathrm{~g}$ of the propolis extract dissolved in $1 \mathrm{~L}$ of great degree grain alcohol. The BRP extract at a concentration of $1 \%$ (previously studied antimicrobial concentration) was incorporated into the fluoridated toothpaste (1500ppm) in the Pharmacotechnical Laboratory at the Federal University of Ceará, Brazil. After identification of chemical constituents by High-Performance Liquid Chromatography (HPLC), dentifrices were formulated with the same flavor, color and odor.

\section{Criteria and Procedures for selection of subjects}

This study is longitudinal, parallel, randomized, double-blind and controlled design. The selection of participants was held in Aracati-CE, town without public water fluoridation. Adolescents were selected under orthodontic treatment and visible plaque in public schools. Individuals who agreed to participate and do not fall into any of the exclusion criteria were met individually, to be given additional information about the study and clarify all remaining questions. After the collection of personal and general health data, they signed the Informed Consent Form (ICF) for participation in the study.

Presence of visible plaque on tooth surfaces, teenagers between 12 and 18 years, caries-free and being right-handed were included in the study. Presented systemic changes related to periodontal health-disease process, previous antibiotic therapy (treatment with antibiotic and/or antiinflammatory) up to six months before the study, users of legal / illegal drugs, use of prostheses, patients with less than 10 elements per dental arch, patients with a history of allergies (asthma, urticarial, rhinitis, sinusitis) patients with a history of hypersensitivity to medicines, foods or other factors, patients with a history of chronic diseases, pregnancy and volunteer not want to continue for reasons other than adverse effects are excluded from the study.

\section{Clinical Period}

Participants received toothbrush of same brand, straight cord, small head and soft bristles and also the dentifrice treatment. All received standard oral hygiene instruction by the same instructor where the following topics were discussed:

Number of brushings: 03 daily brushings (after breakfast, after lunch and before bedtime);

Standardization in brushing technique which was explained similarly to the volunteers and their guardians;

Explanation of the harm that a cariogenic diet may lead to oral health.

Two visits were made:

Visit 01 (Day 0)- Initial clinical consultation, delivery of toothpaste for use for four weeks and oral hygiene instruction;

Visit 02 (Day 28)- Final consultation and application of questionnaires.

\section{RESULTS}

The average age of the participants was 15.1 (+/- 1.7). Figure 1 shows the perception of patients regarding the acceptance of Brazilian red propolis dentifrice on a scale of 0 to 10 . All parameters were above 8 scores.

Regarding possible adverse effects such as nausea, irritation and change in sense of taste, there was only one report of nausea without irritation reports or altered sense of taste (Figure 2).

\section{DISCUSSION}

In recent years, drug and embedded products with bioactive molecules are undergoing a technological revolution that extends from genetic engineering to molecular biology and biochemistry using the most advanced features. This advancement occurring at an accelerated pace is explained by the search for alternatives to synthetic drugs, generally loaded with side effects and the support that science and the expansion of academic and clinical research is offering to drugs based on natural products, stating that popular medicine is in fact grounded by science. ${ }^{4,6,12}$

Bioactive molecules are incorporated in different formulations existing in the market, especially mouthwash, for the dental plaque as Malvatrikids', Anapyon', Clinexidin', Malvatricin Plus Plax Colgate Fresh Tea, Própolis', Calêndula', Malvona', among others. Ribeiro et al. 2015. In addition to the mouthwashes, dentifrices are the most found formulations. $^{12}$

Antimicrobials are widely used by individuals who have plaque build-up, besides chlorhexidine, triclosan, stannous fluoride; the essential oils have gained popularity. Toothpaste with natural products have demonstrated antimicrobial activity in several studies, having widely recommended use, especially against cariogenic and periodontal bacteria. ${ }^{13-15}$

It is known that orthodontic appliances facilitates biofilm buildup, which can cause bacterial imbalance and thus antibacterial substances could be used in plaque removal in individuals who have difficulty in mechanical control of dental plaque. Several studies demonstrate the antimicrobial activity of propolis. Fosqueira et al. 2012 achieved significant results in patients with gingivitis. ${ }^{16}$

Chlorhexidine is the antimicrobial and antiseptic agent most widely used in dentistry, though it is documented that prolonged use causes adverse effects such as a change in color in the dental element, loss of sense of taste, burning of soft tissue, xerostomia, scaly lesions, mucosa ulcerations and unpleasant aftertaste in the mouth. These changes must be controlled and prevented through appropriate use in order to avoid local compromising. ${ }^{4-6,17}$ In the present study were not reported or observed

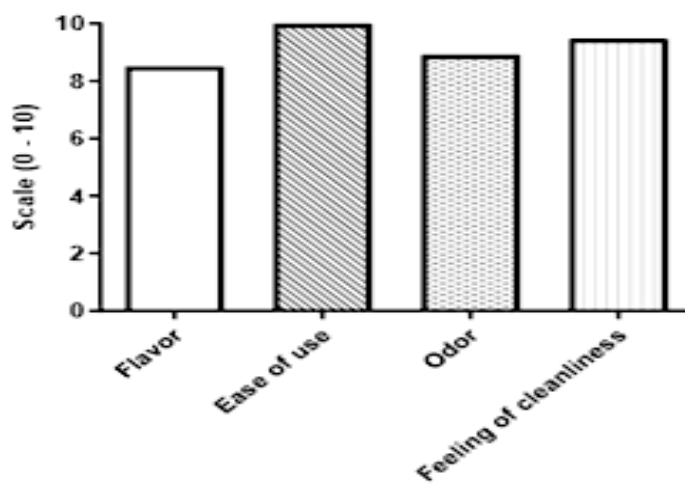

Figure 1: Perception of patients regarding the use of Brazilian red propolis dentifrice at the end of treatment.

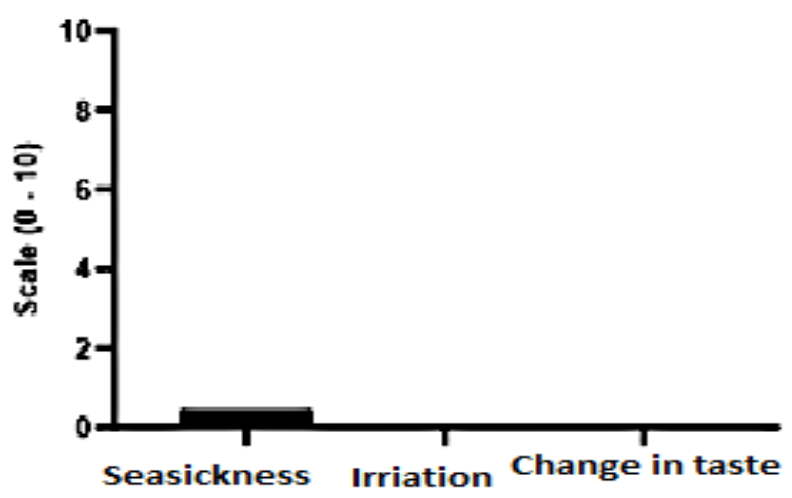

Figure 2: Adverse effects reported by patients following treatment with dentifrice of Brazilian red propolis. 
adverse effects and only one patient reported feeling nauseous when using the dentifrice.

A crossover study by Bhat et al. ${ }^{18}$ showed greater efficiency in reduction of plaque using a dentifrice incorporated with propolis than using the commercial dentifrices tested in the study. Confirming efficacy of this natural compound for its antimicrobial activity.

Skaba et al..$^{19}$ carried out studies which demonstrate the efficacy of preparations containing up to $3 \%$ propolis extract. In such experiments the toothpaste embedded with propolis assisted efficiently in plaque removal and proved to be able to improve the general health state of the marginal periodontium in patients with gingivitis.

Silva et al. ${ }^{20}$ examined the antimicrobial activity of propolis and compared to that of chlorhexidine. In the study propolis showed significant antimicrobial activity, but lower than chlorhexidine.

The consistency of the dentifrice is an important parameter acceptance of the product, since it is responsible the creep dispensation on the brush, spread the mouth, release rate of the flavoring and active ingredients, should all occur at a relatively brief time. ${ }^{21}$ In this study ease of use practically achieved maximum scores. Parameters as the taste, odor and cleanliness, also obtained high scores.

In Dentistry, the clinical use of natural products still finds acceptance resistance, possibly by the dogma that manufactured drugs have guaranteed effectiveness. ${ }^{22}$

Diniz et al. ${ }^{23}$ evaluated the perception of patients after use of essential oil based and compared with mouthwash rinses of cetylpyridinium chloride. In this study the group treated with essential oils rinses showed higher discomfort and burning. Use of oral rinses increases exposure to the oral mucosa alcohol and is not the preferred location for alcohol degradation, but some amount is absorbed and metabolized at the tissue level during swallowing, thus, dentifrices with antimicrobial properties become an option. ${ }^{23}$ In this study there were no reports of irritation, a fact that must be connected to the $1 \%$ concentration of propolis used, resulting in a minimal amount of alcohol in the final preparation.

Toothpastes and rinses formulations containing essential oils obtained seal of acceptance of the American Dental Association (ADA) and have shown to possess excellent tolerability and safety, with no change reported in the perception of flavors by users. ${ }^{24}$

\section{CONCLUSION}

After using for 4 weeks of BRP dentifrice, for patients undergoing orthodontic treatment, it caused no adverse effects and had great acceptance by users.

\section{ACKNOWLEDGEMENT}

We acknowledge all participants and Federal University of Ceara.

\section{CONFLICT OF INTEREST}

The authors declare no conflict of interest.

\section{ABBREVIATIONS}

INPI: National Institute of Industrial Property; BRP: Brazilian Red Propolis.

\section{REFERENCES}

1. Lins R, Vasconcelos FHP, Leite RB, Coelho-Soares RS, Barbosa DN. Avaliação clínica de bochechos com extratos de Aroeira (Schinus terebinthifolius) e Camomila (Matricaria recutita L.) sobre a placa bacteriana e a gengivite. Rev Bras PI
Med. 2013;15(1):112-20.

2. Moura SAB, Medeiros AMC, Costa FRH, Moraes PH, Oliveira FSA. Valor Diag nóstico da Saliva em Doenças Orais e Sistêmicas: Uma Revisão de Literatura. Pesq Bras Odontoped Clin Integr. 2007;7(2):187-94.

3. Cagetti MG, Strohmenger L, Basile V, Abati S, Mastroberardino S, Campus G. Effect of a toothpaste containing triclosan, cetylpyridinium chloride and essential oils on gingival status in schoolchildren: A randomized clinical pilot study. Quintessence Int. 2015;46(5):437-45.

4. Lobo PLD, Fonteles CSR, Marques LARV, Fechine FV, Fonseca SGC, Carvalho $\mathrm{CBM}$ et al. The efficacy of three formulations of Lippia sidoides Cham. essential oil in the reduction of salivary Streptococcus mutans in children with caries: A randomized, double-blind, controlled study. Phytomedicine. 2014;21(9):1043-7.

5. Goes P, Dutra CS, Lisboa MR, Gondim DV, Leitão R, Brito GA, et al. Clinical efficacy of a $1 \%$ Matricaria chamomile L. mouthwash and $0.12 \%$ chlorhexidine for gingivitis control in patients undergoing orthodontic treatment with fixed appliances. J Oral Sci. 2016;58(4):569-74.

6. Valadas LAR, Gurgel MF, Mororó JM, Fonseca SGC, Fonteles CSR, de Carvalho CBM et al. Dose-response evaluation of a copaiba-containing varnish against streptococcus mutans in vivo. Saudi Pharm J. 2018.

7. Anauate NC, Marcucci MC, Paulino N, Anido-Anido A, Amore R, De Mendonça $S$ et al. Effects of typified propolis on mutans streptococci and lactobacilli: a randomized clinical trial. Braz Dent Sci. 2013;16(2):31-6.

8. De Araújo YLFM, De Mendonça LS, Orellano SC, De Araújo ED. Comparação entre duas técnicas utilizadas no teste de sensibilidade antibacteriana do extrato hidroalcoólico de própolis vermelha. Scientia Plena. 2011;7(4):1-4.

9. Bueno-Silva B, Alencar SM, Koo H, Ikegaki M, Silva GV, Napimoga MH. Antiinflammatory and antimicrobial evaluation of neovestitol and vestitol isolated from Brazilian red propolis. J Agric Food Chem. 2013;61(19):4546-50.

10. Paula AMB, Gomes RT, Santiago WK, Dias RS, Cortés ME, Santos VR. Susceptibility of oral pathogenic bacteria and fungi to brazilian green propolis extract. Pharmacologyonline. 2006;3:467-73.

11. Liberio AS, Pereira ALA, Araujo MJAM, Dutra RP, Nascimento FR, MonteiroNeto $V$, et al. The potential use of propolis as a cariostatic agent and its actions on mutans group streptococci. J Ethnopharmacol. 2009;125(1):1-9.

12. Furtado JJH, Valadas LAR, Mendonça KS, de Oliveira FRD, Gadelha LMU, Fiallos NM. A Technological Prospection. Recent Pat Biotechnol. 2018;12(4):288-96.

13. Sunitha J, Ananthalakshmi R, Jeeva JS, Jeddy N, Dhakshininamoorthy S, Muthu MRM. Antimicrobial effect of herbal dentifrices: An in vitro study. J Pharm Bioallied Sci. 2015;7(2):S628-31.

14. Shaheen SS, Reddy P, Hemalatha SR, Doshi D, Kulkarni S, Kumar M. J Clin Diagn Res. 2015;9(4): ZC42-6.

15. Serbiak B, Fourre T, Geonnotti AR, Gambogi RJ. In vitro efficacy of essential oil mouth rinse versus dentifrices. J Dent. 2018;69:49-54

16. Fosquiera EC, Steffens JP, Reinke SMG, Possagno RC, Kozlowski JVA, Rezende ED, et al. Efeito da própolis no crescimento in vitro de microrganismos associados à periodontite em pacientes HIV-positivo. Revista Periodontia. 2008;18(3):77-82.

17. Pegoraro J, Silvestri L, Cara G, Stefenon L, Mozzini CB. Efeitos adversos do gluconato de clorexidina à 0,12\%. Journal of Oral Investigations. 2015;3(1):33-7.

18. Bhat N, Bapat S, Asawa K, Tak M, Chaturvedi P, Gupta WV, et al. The antiplaque efficacy of propolis-based herbal toothpaste: A crossover clinical study. J Nat Sc Biol Med. 2015;6(2):364-8.

19. Skaba D, Morawiec T, Tanasiewicz M, Mertas A, Bobela E, Szliszka E, et al. Influence of the Toothpaste with Brazilian Ethanol Extract Propolis on the Oral Cavity Health. Evid Based Complement Alternat Med. 2013. ID 215391.

20. Da Silva A, Ferreira FDCA, Capel LMM, Botelho MPJ. Avaliação in vitro da Atividade Antimicrobiana de Extrato Alcoólico de Própolis Comparado à Solução de Clorexidina 0, 12\%. J Health Sci. 2017;19(2);95-7.

21. Nunes RS, Lira AAM, Lacerda CM, Silva DOB, Silva JA, Santana DP. Obtention and evaluation of odontologic products made with the crude extract of Lippia sidoides Cham (Verbenaceae) over the dental biofilm. Rev Odontol UNESP. 2006;35(4):275-83.

22. Bettega PVC, Czlusniak GR, Piva R, Namba EL, Ribas CR, Grégio AMT, Rosa EAR. Fitoterapia: dos canteiros ao balcão da farmácia. Archives of Oral Research. 2011;7(1):89-97.

23. Diniz PA, Lima CF, Fernandes EE, Joias RP, Rode SDM. Percepção dos pacien tes em uso de enxaguatórios bucais: óleos essenciais e cloreto de cetilperidíneo. Revista da Associaao Paulista de Cirurgiões Dentistas. 2014;68(3):245-9.

24. Charles CH, Sharma NC, Galustians HJ, Qaqish J, McGuire JA, Vincent JW. Comparative efficacy of an $\mathrm{CH}$, antiseptic mouthrinse and an antiplaque/antigingivitis dentifrice: A six-month clinical trial. J Am Dent Assoc. 2001;132(5):670-5.

Article History: Submission Date : 15-02-2019; Revised Date : 17-03-2019; Acceptance Date : 29-03-2019.

Cite this article: Silva MDA, Valadas IAR, Júnior FJG, Oliveira GALD, Neto EMR, Ponte ED, et al. Perception and Adverse Effects of Patients after using Propolis-Containing Dentifrice. J Young Pharm. 2019;11(4):421-3. 